\title{
Teacher education in Ireland and Western Europe: A comparative analysis
}

\section{John Coolahan}

To cite this article: John Coolahan (2001) Teacher education in Ireland and Western Europe: A comparative analysis, Irish Educational Studies, 20:1, 335-368

To link to this article: https://doi.org/10.1080/0332331010200126

册 Published online: 18 Jul 2008.

Submit your article to this journal ¿

Џll Article views: 244

Citing articles: 7 View citing articles 5 


\title{
TEACHER EDUCATION IN IRELAND AND WESTERN EUROPE: A COMPARATIVE ANALYSIS
}

\author{
John Coolahan
}

\section{Introduction}

It is not an easy task to provide a succinct overview of key features and trends in pre-service teacher education in Western Europe. Formal teacher education is deeply rooted in most European countries dating from the late eighteenth or early decades of the nineteenth century. Education systems and teacher education have been shaped by the historical, political, economic, cultural, religious and linguistic differences which have characterised the independent nation states of Europe. This has given rise to great diversity and variation of approach in teacher education. Yet, despite the diversity shaped by historical circumstances, there is also a growing commonality in the issues and trends emerging in the different Western European systems. The paper will be primarily concerned with these general trends, while recording the caveat that the generalisation cannot do full justice to the rich tapestry which exists in European teacher education. Limitations of time and space also necessitate concentration on teacher education for the mainstream primary and secondary schools.

The approach taken in this paper is that, in contemporary society, it is not beneficial to view teacher education as a discrete, compartmentalised entity. Rather, it needs to be viewed within much broader parameters wherein its relationship with a fast-changing society is kept to the fore. In line with this changing society, new roles are being devised for schools which themselves are serving the needs of a more diverse clientele who face new pressures, challenges and opportunities. Educational policy in developed countries has 
been moving from the concept of the schooled society to the learning society, with lifelong learning as the animating principle. Lifelong learning is a particularly apt concept for teachers as an occupational category in contemporary society. In planning for teacher education in the twenty-first century, it would be particularly regressive to over concentrate on pre-service teacher education, which was the nineteenth century model. Pre-service teacher education is of crucial importance but must be seen within the broader context of the teaching career, which itself must be re-interpreted in the context of changing human, social, cultural, economic and justice needs.

The paper draws attention to some of the key elements which are shaping European society. It also highlights ways in which the role of the school as a social institution is being re-shaped as well as how nonschool educational agencies are evolving against this background. It seeks to give a pan-Western European overview of a set of interconnected elements which affect teacher education recruitment, entry to teacher education, institutional arrangements for pre-service teacher educational course structure and duration, curriculum, schoolbased experience, educational research, staffing, evaluation, induction, in-service education career opportunities. An attempt is made to position Ireland's experience within the Westem European framework, drawing attention to particular strengths and weaknesses.

In Western Europe, the European Union has expanded to incorporate fifteen member states and there are plans for further expansion early in the new century. Up to the nineties the issue of education, as distinct from training, was jealously guarded as the prerogative of the member states. However, since the Maastricht Treaty of 1992 and the Amsterdam Treaty of 1997, the European Commission has taken a more proactive role in educational affairs within the Union. In 1995 the Commission issued its first white paper on education - Teaching and Learning: Towards the Learning Society - and in 1996, adopted "A Strategy for Lifelong Learning" as a policy goal. To improve the mobility of teachers within the European Union, a Directive (89/48/EC), came into effect in 1991, which guaranteed mutual recognition of teacher qualifications on certain conditions. Many schemes exist which are aimed at promoting exchanges between teacher education and student teachers within the member countries. 
Such developments have created a new interest in comparability of teacher education programmes and encouraged a greater degree of consultation and review about the issues involved. Teacher education is a major enterprise in Europe. More than half a million student teachers receive their initial teacher education in more than 1,000 institutions at which more than 50,000 teacher educators and trainers are working. In-service education has to be provided for more than five million in-career teachers (Buckberger, 1994, p.15). It is not surprising that a number of surveys of European teacher education have been published in recent years (Bone and McCall, 1990; Coolahan, 1991; Neave, 1991; Vonk, 1991; Buckberger, 1994; Sander, 1994; Galton and Moon, 1994; Michaelsson, 1995). Many seminars and conferences have been held, most noticeably by the Association for Teacher Elucation in Europe (ATEE), which have highlighted issues and development in European teacher education and have sought to foster greater harmonisation within the inherited variegated framework. A particularly useful publication in this context was the ATEE's Guide to Institutions of Teacher Education in Europe, (ed. Buckberger, 1995). This publication gives an overview of key features of teacher education in twenty six European countries and gives details on teacher education institutions in the different countries.

While harmonisation efforts are seen to be important, teacher education in Europe is by no means in a static condition. A great deal of on-going critical analysis and review has been occurring. Adjustments, re-orientations and reforms are being regularly incorporated within teacher education. Many governments have been commissioning reviews and academics have been exploring new ways forward (cf. Elliot, 1993; Hudson and Lambert, 1997). Some of these trends are dealt with in relevant sections of this paper.

\section{A Changing Society}

An education system needs to serve the needs of society and when that society is undergoing profound and accelerating change, then particular pressures emerge to establish an alignment between the education system and these changing societal needs. The teaching profession is a key mediating agency for society as it endeavours to cope with social change and upheaval. But the teaching profession 
must be trained and equipped so that it will have the capacity to cope with the many changes and challenges which lie ahead. If it is to retain the confidence of society, the teaching profession must adapt a great deal so that it can act in a constructive manner within a fastchanging society. To understand policies and trends in teacher education, it is necessary to view them in this context. A fastchanging society has new aspirations for a changing school which, in turn, calls for changes in teacher education and in the teaching career.

Many profound social changes need to be addressed. These include the accelerating impact of the knowledge explosion and the significance of the "knowledge-base" for economic and social development. The promotion of the "knowledge-based society" or the "learning society," is emerging as a generally accepted aim. The globalisation of economies is giving rise to extensive changes in the location of canital and labour. Increasing competitiveness is putting a premium on human potential. Linked to this is the pervasive influence of new information and communications technology. The ramifications of such technology are very extensive for occupational and cultural patterns. The educational system needs to incorporate such technology much more as a learning tool but also to promote competence in the utilisation of such technology by young people for the world they will now experience. Lifelong leaming for all has become the policy goal as we face into the new century, and this has many ramifications for traditional schooling patterns.

The family, as a social institution, is under great stress and change internationally. The extent of family breakdown, new forms of family relationships, single parent families, and so on, create problems for many young people. More pressure is being placed on the school as a counterbalance to compensate for some of the difficulties being encountered. There is also a relative decline in the status and influence of the churches and older authority agencies on young people in contemporary society. Again, the school is being called upon more and more by social agencies to provide programmes and remedies for defects in the social fabric external to the school.

The influence of the mass media and advertising have become a very pervasive feature in our civilisation and sometimes operates in an exploitative way in relation to young people. It is also the case 
that young people are increasingly exposed to destructive subcultures such as drug abuse which often creates great tension between the culture of the school and the peer sub-culture outside the school.

The large increase in unemployment in many countries, and rapidly changing unemployment patterns, also raise new challenges for the school. Chronic unemployment has very serious deleterious consequences for many families, particularly for those most disadvantaged in conurbations where unemployment is very high and appears to be endemic. Sometimes this coincides with other problems being experienced by immigrant groups. Even where employment is available, it is undergoing very rapid change and now involves much insecurity and uncertainty. Such instances of contemporary social change highlight the changed interface which exists between school and society and serves to draw attention to the changed agenda for the school as a social institution. Most European societies are becoming more multicultural in composition which poses challenges to traditional schooling patterns, as well as to the broader cohesiveness of democtacies founded on the principles of equality of citizenship. It is also the case that societies committed to greater economic growth and material development face the challenge of environmental sustainability, so that the growth can be managed in such a way as to conserve and pass on to other generations the resources of the planet in a manner which is sustainable into the future.

Such instances of contemporary social change highlight the changed interface which exists between school and society, and serves to draw attention to the changed agenda for the school as a social institution.

\section{The Changing School}

In European countries, the traditional emphasis of the school's role in promoting the intellectual and cognitive development of the child has been extended to emphasise more the pastoral, socialising and counselling role. In the context of some of the social changes alluded to above, the school is being required to take more care of the affective and emotional development of the young people who spend a significant portion of their childhood and youth within the school. Neave is surely correct when he draws attention to the "major 
enlargement in the area of responsibility which teachers are expected to assume" (Neave, 1991, p.32). In all countries there has been a massive expansion of pupil participation in secondary type schooling over the last twenty-five years and the pupils are participating for a much more extended time-period. These schools now deal with a very heterogenous pupil clientele with varying levels of intelligence, application and aspiration. They require changed responses from the schools in terms of experience and relationships. All school systems have been engaged in major programmes of curricular, pedagogic and assessment reforms. A key feature of this is the incorporation of I.C.T. as a normal feature of the teaching-learning relationship in schools. Schools are also seeking to adopt a more focussed approach t1) the changing world of work, experimenting with work experience, school-industry links, and so on. The situation is particularly acute for the significant minority of under-achievers and alienated young people which all the school systems have and for whom traditional employment opportunities have largely disappeared.

The promotion of greater gender equity within schools in terms of curricular content and choice, pedagogic styles, and interpersonal relationships is also an unavoidable challenge to contemporary schools. Furthermore, each of the countries has adopted a policy of greater integration of the disabled within normal schooling, which presents challenges of various kinds, and requires improved resourcing. In almost all the countries under review the issue of multi-cultural education is one which has to be coped with. Some schools, particularly in large urban centres, need to respond to pupils of varied colour, religion, language and local culture. The rights of all children have been underwritten by the U.N. Convention on Children's Rights (1989), but responding in satisfactory ways presents problems for school administrations and teachers. Schools in this region are also being encouraged to promote a greater European dimension in their formal and informal activities. The increasing impact which the E.U. is having on the lives of citizens needs to be reflected in the education of the young Europeans involved.

European schools are being required to relate more effectively with parents and local communities. This requires more time, and, for some teachers, new skills. Furthermore, official policies are encouraging greater autonomy for schools, whereby a "bottom-up" 
approach is being encouraged in devising school plans and school reports. Greater staff collaboration and collegiality are being sought and "Whole School Development" is being encouraged. For many teachers these trends involve new professional responses, placing new demands on them. In line with general public policy, new emphasis is being given to accountability and transparency in school affairs, particularly in the utilisation of public funds. The overall impact of such new emphases on schooling can be seen, on accumulation, to amount to a very changed concept of the school from what existed a generation ago.

Social policy has again re-emphasised the concept of "Education as Investment" in social renewal and development. Investment in human capital and human resources development is now the orthodoxy for European societies. For many reasons, it is realised that nurturing and promoting the talents and potential of all the people in European states is a vital dimension for the achievement of individual self-realisation and for the promotion of social, cultural and economic progress leading to greater social cohesiveness in democratic societies.

Schools are also operating within a legal framework in an increasingly litigious-conscious society. The care and protection of young people and their rights has become a more sensitive and a more complex issue. With the development of lifelong learning policies and more integrated and co-ordinated approaches to social exclusion, school personnel are expected to liaise more with nonschool educational agencies. This is part of a trend for school to become more permeable to others in their communities with educational responsibilities and interests.

The range of such aspirations for school as a social institution highlights the need for some fundamental thinking about the future of the school. The school we have inherited has been shaped by an earlier social era, for very different social and individual purposes. The inherited mould is creaking and it is under considerable stress. There is a strong danger that we may be seeking too much from it in too short a time, without sufficient attention to the extent of the changes involved. In my view, there has been insufficient planning for the nature and character of the school as an institution for the 21 st century. 
Something of a new social contract needs to be arrived at which will merge aspirations and reality more satisfactorily. There is also a need to plan with some vision, daring and resourcing to ensure that European society has the calibre of teachers required to meet the challenges of the teacher's changed role.

\section{What Kind of Teacher?}

Various international agencies have indicated an awareness of the profound character of the societal change which is afoot and have highlighted the centrality of a qualitative teaching force. For instance, the E.U. Study Group on Education and Training stated:

Teachers play a primordial role because they are the people in our societies providing a service of such a marked multidimensional character. Contemporary trends are that their role is becoming even more multi-faceted, because it increasingly incorporates social, behavioural, civic, economic and technological dimensions. (Accomplishing Europe Through Education and Training, 1997, p.131)

The UNESCO Commission on Education in the Twenty-first Century noted as follows:

The importance of the role of the teacher as an agent of change, promoting understanding and tolerance, has never been more obvious than today. It is likely to become even more critical in the twenty-first century. The importance of the quality of teaching, and therefore of teachers, cannot be over -emphasised. (UNESCO Learning: The Treasure Within, (1996), pp.141, 146)

It is quite clear that the qualities required of teachers to meet increasing demand include the following: well-educated, intelligent, competent in subjects, understanding, imaginative, highly-skilled, caring, innovative, committed, motivated, team player, skilled communicator, a lifelong learner.

At first sight, it may seem that such a list of qualities is idealistic and somewhat unreal. On the contrary, I would argue that 
these are the real, common sense qualities which the job demands, and, thankfully, which many teachers already exhibit. It is crucial that the range of inter-connecting elements of teacher education and of the teaching career are such that they support and promote such qualities. Without a high quality teaching force the well-being of future society becomes dangerously imperilled. How then do Western European societies organise such matters?

\section{Recruitment/Entry to Teacher Education}

In the context of a teaching profession facing a major enlargement of responsibility, it is to be expected that recruitment to the profession should be a matter of growing concem in many European countries. While the attraction of applicants with high intelligence, good imagination and caring attitudes is clearly desirable, the actual pattern of recruitment varies a great deal between different countries. In countries where, traditionally, teachers have been accorded good social status, the quality of recruits is high. Thus, in countries such as Scotland, Sweden, Finland, Norway, Iceland, there is high competition for entry into teacher education courses. In Germany there is a policy of "open entry" and some of the federal states have an over-supply of teachers. In England, the teaching profession came under a lot of criticism during the Thatcher era and a somewhat poor public image was reflected in the media. Teacher shortages exist in a number of subject areas and the government has taken out large scale advertisements to encourage more applicants to opt for teacher education. Despite this, and incentives for certain subjects, shortages continue to exist (T.E.S. 19/11/99). In the Netherlands, a pattern of heavy drop-out from the teaching career has tended to deter applicants from the higher ability range. Overall, a mixed picture emerges on the attractiveness for young adults to the teaching career. Analyses of the contemporary societal context highlight the necessity of building a favourable image of the career and conditions of work of teachers if quality personnel are to be recruited for the future.

It would seen that a less than favourable public image of the teaching career may be highly influential in another general phenomenon which is the feminisation of the teaching profession. This is an international trend and is very pronounced in primary teaching, which has become preponderantly female. This is so even 
in countries where teacher salaries are relatively high. The imbalance is a cause of concern and several states have sponsored research on why teaching is not attracting more males. As yet, no successful strategies have been devised to restore a better male-female balance.

Entrance to teacher education courses is mainly based on the results of terminal secondary school leaving examinations, particularly for concurrent and primary teacher education courses. Entry to the teacher education element of the consecutive courses is based on the performance of the applicant in university degree examinations. However, most countries now allow, and indeed encourage, more varied routes of entry. Provision is made for "mature" student entry and for applicants bringing wider work experience to bear. This is seen as providing an enrichment to the teacher student boxly and improving the range of work experience of the teaching body. Some countries supplement the academic performance criterion with personal interview or aptitude tests, but these are seen to have logistical and validity problems.

Efforts are also being made, particularly in the concurrent courses, for students to spend part of their training on exchange programmes in other European countries to promote "European dimension" (Beernaert, 1995). However, hitherto, the numbers participating have been less than anticipated, although language teachers experience exchanges in the country of their foreign language(s) on a regular basis. In most countries, the state, either directly or indirectly, monitors the supply and demand situation, albeit with some flexibility, as it is realised that demographic forecasting is a very inexact science. The demographic downtum experienced by many European countries in recent times has led to a "greying" profession with insufficient " new blood" entrants. The "generation gap" assumes greater significance in the context of some of the social changes alluded to above. The response of some governments has been to introduce early retirement schemes and increase secondments of classroom teachers to in-service work etc., and so open up some new recruitment opportunities.

Ireland is comparatively fortunate regarding the quality of its recruits into teaching. The career of teaching has traditionally enjoyed high social regard and that this view continues has been 
reflected in a number of attitudinal surveys on careers. There is high competition for entry to both primary and post-primary teacher education. The academic performance levels are high and candidates tend to bring many fine personal and cultural qualities to the job. This is a priceless asset, which should not be taken for granted. Ireland does, however, share the general European pattern of feminisation of the career. The modes of monitoring supply and demand have been weak and more sophisticated and sustained attention to this issue is necessary. Not much thought has been given to the "greying" of the career issue. In the context of the demands on teachers within a changing society, it may well be that conceiving a career in teaching for four decades or more may be an outdated view. The vast majority of recruits to teacher education in Ireland enter on the basis of their previous academic achievements.

\section{Institutional Arrangements}

Over recent decades, the massive expansion and extension of pupil enrolment, developments in educational studies, aspirations of teachers, among other factors, have altered the traditional institutional arrangements. In most European countries there has been a strong tendency to assign to the universities or polytechnics a more fundamental role in the education and training of all teachers (Judge, 1991; Michaelsson, 1995). This has been generally interpreted as an ungrading for the teaching profession involving a deepening of the academic knowledge base and an opening up of a greater research orientation for trainee teachers.

Within the universities, education departments have been winning greater status than they had formally enjoyed: staff are expected to hold postgraduate qualifications in educational studies and to engage in research. As well as pre-service courses, there has been a large expansion in the provision of postgraduate in-career diplomas on specialist areas such as curriculum, management, guidance and counselling, as well as in masters' degrees and doctoral programmes. This is regarded as providing a benign academic cycle whereby initial teacher education, in-service career studies and educational research enrich each other. It also promotes greater career diversification. 
The following chart indicates the changing work profile of education departments in Irish higher education.

\section{Changeng Profile of Education Departments}

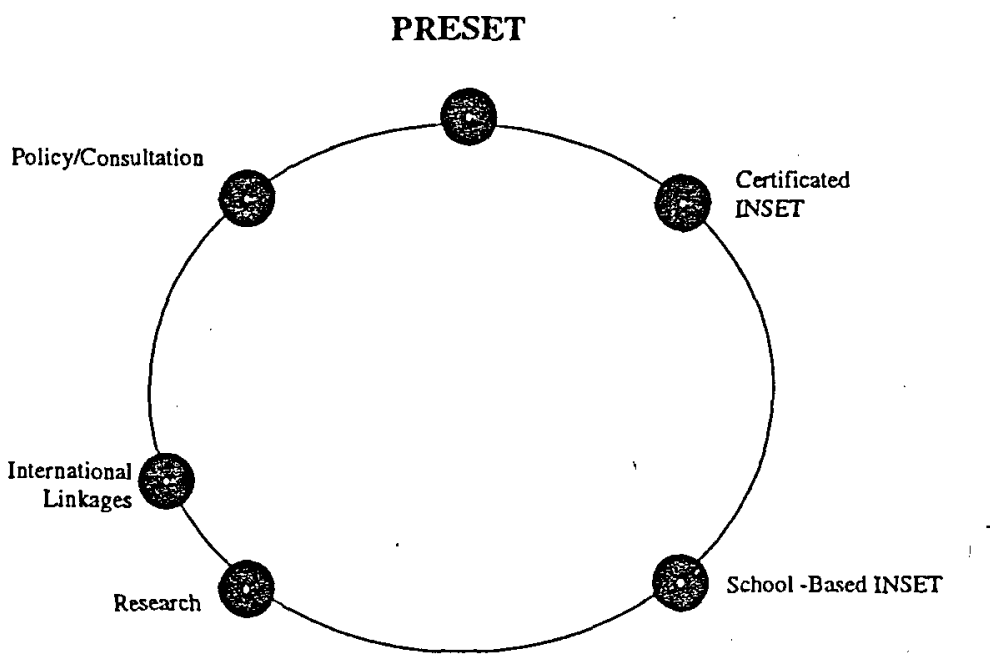

Pre-service teacher education continues to be a central concern. However, this has been supplemented by a wide range of post-graduate and in-service courses leading to university qualifications. Departments also tend to engage in more school-based in-service work, mostly of a short-term character, but sometimes of a longitudinal nature. Educational research by staff and post-graduate students is strongly established. Staff also contribute to national policy formulation and act in consultancy capacities to many educational organisations, as well as participate in official commissions or reviews on educational issues. Relationships tend to be cordial between staff in teacher education and other agencies such as the Department of Education and Science, teacher unions and managerial bodies. The characteristics profiled here were not always in evidence, but reflect significant progress, and place education departments in a more favourable position than exists in many European countries. 
The promotion of a greater influence of the university on teacher education was accompanied by some apprehension that this would lead to an over-theoretical approach to the loss of pedagogical and applied teaching studies, which was more associated with the mono-purpose training college tradition. However, while some concern still exists, the apprehension has been largely alleviated, with pedagogical studies and classroom-focussed research getting serious attention. This may have been facilitated by the nature of the negotiations and arrangements arrived at by the non-university and the university institutions. The pattern of alignment varies, sometimes involving amalgamation, but often allowing for more of an association arrangement for course validation and awards, rather than for full absorption into the university's institutional framework. This has sometimes allowed for the best aspects of both the university and training college traditions to fructify each other with an improvement in both the quality and status of teacher education. As with other professions, the greater involvement of the university in teacher education has led to a reduction of the role of the state, particularly on issues such as course content.

The Irish experience of "universitisation" of teacher education, was largely achieved in the early seventies. It was achieved harmoniously with very little institutional friction (Coolahan, 1991a), unlike some other countries (see Baukje J., B. van Kesteren and G. Doonnekamp "The Effects of Mergers," 1991). The Irish experience coincided with the move to a fully graduate profession which operated on a common basic salary scale for all categories of primary and postprimary teachers. This latter trend is also unusual in a Western European context, but has helped to unify the teaching profession in Ireland.

A notable divergence from the strengthened influence of the university in teacher education is the case in England. Here, the government moved to control the structure, content and evaluation of teacher education in a more direct manner. While teacher education in England is linked to the universities, government appointed bodies have intervened to reduce the academic educational studies' input to professional studies in favour of methodological studies and a much more school-based approach to training. This has been a controversial issue and has been criticised as a shift towards a technicist rather than a professional approach to teacher education (Aldrich and Crook, 1998 ). 
Germany has for long operated a dual model whereby the preservice "theoretical" preparation is done at stage one in the university, while stage two, leading to full qualification, takes place in the school. In the light of changing trends and needs, it has been suggested by commentators there that closer cooperation should exist between those responsible for each stage. The process of "universitisation" has not been fully promoted in Belgium, but a great deal of rationalisation of the provision of colleges of education has taken place. A somewhat similar pattern has occurred in Denmark with a reduction of teacher colleges of education from 30 to 18 in the decade 1982 to 1992 . Teacher education there has not been absorbed by the university and much of the in-service education takes place under the auspices of a specialised institution - the Royal Danish School of Educational Studies - which also has the right to award Masters and $\mathrm{Ph} . \mathrm{D}$ degrees in education. One of the problems of the pre-service courses there, has been their over-crowded content and their accompanying examinations (B. Elle, 1995).

\section{Course Structure and Duration}

Two predominant models of course structure have evolved in European teacher education, the concurrent and the consecutive model. The concurrent model involves a three or four year course, in the main, with academic subject knowledge, e.g. mathematics, history, being combined with educational and professional studies throughout the course duration. This model has been particularly favoured in primary teacher education but can also be found for secondary teachers, particularly relating to special subjects such as Home Economics, Physical Education and craft subjects. The predominant model for secondary teachers has been the consecutive structure whereby students complete their undergraduate degree in their subjects, e.g. science, languages, and then concentrate for a year or two on their educational and professional studies. Variations also exist, focussed particularly on "mature" students or those with work experience. England experimented with "licensed" and "articled" teachers who would not have to follow traditional teacher education routes but could obtain qualified teacher status through a successful apprenticeship process. However, the numbers involved have not been significant as a proportion of all teacher recruits. In some countries, e.g. Denmark, the Netherlands, Sweden, there has been a 
trend to combine teacher education for the primary and junior cycle of secondary education, usually in a concurrent process. Training for senior cycle secondary in these countries is on the consecutive model. Over the years, opinion has varied as to the advantages of the concurrent and consecutive approaches over the other; but at present, it seems that each model is regarded as fulfilling valuable functions in response to emerging needs of systems and individuals.

As could be expected, in the light of the increasing responsibility of the teacher's role and the university linkages, the duration of courses, particularly for primary teachers, has been extended from two to three and four years, over recent decades. However, where concurrent courses are of just three years duration, or where there is only one year available for education studies in the consecutive model there is pressure for more time to be available so as to satisfactorily achieve course objectives (Burke and Coolahan, 1995). Students are faced with so many and varied demands, that there is little time to reflect on their course content and their experience in a satisfactory manner. This feeling of pressure is probably linked to the inadequate institutionalisation of a 3 I's (Initial, Induction and In-service) policy on teacher education. This concern about the limitations of time and space to do justice to the needs of pre-service teacher education for the changing school is a very real one among Irish teacher educators. Sometimes, the phrase "more of the same" is used pejoratively of teacher educators who seek more time or better structures to support the needs of teachers for tomorrow's schools. Indeed, it is not "more of the same" we want but, the fear is, that this is what policy makers may give. It is precisely because we are aware of new needs, new challenges and new capabilities, that changes are being sought to underpin, more satisfactorily, all stages of a demanding teacher career which can extend for four decades or more. In seeking more time, better resources and a more enlightened public policy on supporting the teaching career, teacher educators wish to build on what has been shown to be valuable and to extend and develop needed approaches and new forms of partnerships. 


\section{Curriculum}

The issue of curriculum in pre-service teacher education has become a matter of major concern, debate and research in most countries. Bearing in mind the extent and pace of societal change and the challenges facing schools, set out above, it is no surprise that programmes of teacher formation would be subject to much scrutiny and development. Modern teacher education pays attention to the knowledge, attitudes and skills required by the beginning teacher but also seeks to equip the beginning teacher with the ability and motivation to continue learming throughout his/her career. There is a large degree of commonality in the general content of programmes in most European countries. The content can be grouped into four key elements, as follows:

- $\quad$ academic subjects, e.g. science, history;

- studies in educational sciences, e.g. psychology of education, sociology of education;

- methódologies, subject didactics;

- teaching practice.

There are, of course, variations in content, sequence and balance of these components, but they form the structural framework of programmes.

Whether in the concurrent or consecutive models, the tendency is for the treatment of academic subjects to proceed in a relatively discrete manner from the other "educational" components. The rationale behind studies in the educational sciences is to provide the teacher with a framework of reference and understanding to underpin approaches and practice. It is considered that the "foundation" disciplines of education such as philosophy, psychology, sociology, history, curriculum theory when dealt with in an applied, targeted way, help the teacher towards a critical awareness of the schooling system, the social context, stages of pupil development, underpinning values, curricular issues etc. which is necessary for professional work. Traditionally, there has been some criticism about a gap existing between theory and practice. Most courses have adapted to incorporate an applied dimension in the themes dealt with, and sometimes, a problem-solving, thematic approach is taken, with some 
teamwork by subject specialists. In England, there has been a major reduction in the study of the educational sciences in favour of an almost exclusive emphasis on methodologies.

General teaching methods and specific subject methodologies form a core component of courses. In the past, this dimension of university-based courses was regarded as weak and inadequate, but now all courses pay increased attention to methodology aspects. This is sometimes further complemented by the use of video camera work, sometimes employed in micro-teaching techniques and in follow-up analyses of videod classroom practice. As part of an emphasis on promoting self-reflection among student teachers, some are trained in self-analysis techniques with the help of audio-visual technology and computer applications. Staff involved in subject methodologies in some countries have relevant and recent experiences of the classroom and of curriculum development in relation to the subject. This is a requirement of full-time staff in England. In Ireland, in post-primary teacher education, there is a tradition of highly skilled and experienced subject teachers making their expertise in subject methodologies available to students, on a part-time basis. Efforts are also made to provide variety in the methodology sessions using demonstration videos, workshop and active learning methods. Student teachers for primary schools tend to take a broad range of subject methodologies in keeping with their more generalist role, while those for secondary schools, particularly upper secondary, concentrate usually on one or two subjects. In many countries, school curriculum reform has been a "rolling" and on-going issue. In response to this, curriculum studies and curriculum innovation skills are assuming a greater role than formerly in teacher education.

As information and communications technologies have become such a major feature in knowledge production, access and dissemination, most European countries have greatly increased their interest in integrating them with school life, in recent years. It is now accepted that all student teachers need to be equipped so as to make the most effective use of ICT in their teaching activities. While there is more progress to be made, the pace of change in this regard has been impressive, and, of course, a major push is also afoot in the inservice area. 
Many of the social and school changes are influencing the content of the curriculum in teacher education. Some of these developments are particularly worthy of note. The multicultural character of modern society, particularly in urban contexts, calls for more attention to the educational and methodological issues involved. Many European countries are promoting greater integration of pupils with disabilities into mainstream schooling and this also calls for more attention to aspects of special education in teacher courses. Furthermore, research has been highlighting gender inequalities in the structures and processes of schooling, and student teachers are being alerted to and given guidance on equality of gender treatment in school. The rights and role of parents in school systems have been given much greater prominence by most European countries in recent times. Formerly, the links between teachers and parents could be rather distant and tentative. This is no longer the case, and components of teacher education courses deal with teacher-parent relationships, encouraging student teachers to view the parents as genuine partners and to adopt positive, co-operative links with parents. Ireland follows this broad European approach in its curriculum for teacher education. Efforts are made to exemplify a wide variety of methodologies, e.g. lectures, tutorials, seminars, workshops, "hands-on" technology sessions, video recording, small group work, individual guidance and feedback, but the large class groups which often exist inhibit the satisfactory implementation of such techniques. It is generally felt that students would benefit greatly from more engagement with experiential leaming and small group techniques.

\section{School-Based Experience}

The practice of teaching in schools under supervised conditions is a long established component of teacher training programmes. It was a particularly prominent feature of primary teacher training, less so at secondary level. Indeed, it is still the case that practical teaching experience is not required for recognition for secondary teaching in Italy (Todeschini, 1992). Even though the influence of the university has become much more pronounced over teacher education and training, there has been an accompanying concern that practical experience should be given a great deal of attention. An older emphasis on apprenticeship and manuals of teaching method has given 
way to a more professional emphasis whereby student teachers are assisted in forming understandings, attitudes and skills in critical and reflective ways (Zabalza Beraza, 1996). Increasing importance is being laid on the school as a "site" for helping students to understand the dynamics of classtoom teaching and the principles underlying it.

Student teacher placemient in schools usually takes the form of continuous participation for days or time periods throughout the school year, or block placement whereby trainees are located in the schools on a full-time basis for periods over the duration of the course. Block placement tends to be more characteristic of the concurrent course model, which allows more variety in school placement experience than the consecutive model. Both models are in operation within Irish teacher education. There is also a move away from just focussing on teaching practice during school placement towards broader features of school experience, including supervision, examinations, staff meetings, parent meetings, planning sessions, extra-curricular activities. The duration of school-based experience varies in different countries, but, in almost all of them, it is getting greater policy emphasis. As a contrast to Italy, the United Kingdom has taken the most radical approach by greatly increasing the time spent on school experience, giving much greater authority to school personnel, and reducing the time spent in the university. In Germany, the practical experience dimension occurs in the schools following the completion of academic studies in the universities, with only limited contact between school and university personnel. While reforms in Spain on teacher education have been welcomed, there is criticism that the attention to the practical aspects is inadequate at both primary and secondary levels (Montané and Bordas, 1992) Most other countries blend in the school-based experience as an important contributory element to the training programme, with the training institution having the greater degree of responsibility for its evaluation.

The increased emphasis on school-based experience has highlighted the need for more overt partnerships between the schools and the training institutions. These take many forms, but in no country is the emphasis on the school as partmer as strong as it is in the United Kingdom where re-allocation of funding as well as responsibility from the university to the schools has been politically decreed (Townsend, 1994). However, this may entail a danger of 
reversion to a form of apprenticeship which could be a conservative and narrowing force. As a counter to this danger, much attention is being focussed on the role of co-operating teachers and school mentors and how these roles can be best promoted and operated (Zanting et al., 1998; Edwards, 1998; Koster et al., 1998). Developments in the training of mentors also have useful spin-off effects for induction and in-service teacher education (Moon, 1996). To ensure successful outcomes of the partnership approach there is a good deal of preparatory and organisational work involved by both universities and schools, with attention paid to aims, procedures, monitoring; and the student teachers' voice needs to feed into such arrangements. As yet, the role of mentor has not been formally established as a career post. Mentors usually operate from professional goodwill motives and many testify that they too benefit from the work of student teachers who often exhibit new ideas and approaches. Teachers in Irish schools tend to be co-operative and generous in their guidance of student teachers. However, there is significant scope for improving the linkages between schools and education departments in the interests of improved teacher education in Ireland.

The responsibility for evaluating student teachers' performance remains, in most countries, the responsibility of the teacher educators. Most consider that the absence of a responsibility for evaluation on the school mentor allows more freedom and openness to the relationship between student and mentor. However, in most systems the advice or general views of mentors are elicited and are bome in mind by the evaluators. The complex professional skills involved in successful supervision or mentoring of student teachers have not always been formally recognised. The status of this work is likely to improve as new systems of partnership and the emphasis on quality practice take hold. The frequency of visits to schools by institutional supervisors varies in different countries, and depends on course format. Criticisms tend to be voiced that the visits are not frequent enough for satisfactory formative feedback to students.

One of the key concerns in modern European teacher education is to establish a greater inter-penetrative influence between theoretical inputs and practical teaching experience. It is realised that in preservice education, where the student's main concern is to surmount immediate challenges, the content from the foundation disciplines may 
not always achieve their full import. Thus, seminars, tutorials, interaction analysis, dialogue on practice are utilised to add a more problem-focus to issues and to tease out the linkages which can exist between theory and practice. Student teachers are often given the teaching supervision schedules of the supervisors and encouraged to engage in mutual discussion of elements of the practice, sometimes with reference to research findings. Increasingly, the aim is to help the student teachers to be self-analytical and reflective on their own practice. The availability of audio-video recordings of performances is a valuable tool for this process, and repeated analysis can take place back in the training institution.

The influence of Schon and the "Reflective Practitioner" movement has been widespread and is a motivating factor in the new emphasis on practice. Schon characterised the "reflective practicum" as "learning by doing, coaching rather than teaching and a dialogue of reflection-in-action between the coach and the student" (Schon, 1987, p.303).

The close co-operation between teacher education institutions and schools is also desirable for the promotion of an emphasis allied to that of the reflective practitioner - the emphasis on the teacher as action researcher. The student teacher does not have the experience to engage in large-scale research, but action research exercises can be highly illuminative of practice and prompt remedial action where this appears desirable (Drudy and Ui Chatháin, 1999). Teachers can be helped to identify specific areas of their work and guided to research it in a structured way compatible with their experience and circumstances (Collins and McNiff, 1999).

\section{The Research Dimension}

The interest in action research forms part of a wider interest in aligning teachers' work with educational research. The research dimension is also linked to the greater influence of the university on teacher education. While investment in educational research may still be less than is necessary or desirable, more attention is now being focussed on the role of research for all levels of teacher education. A notable instance of this was the international conference organised by the Association of Teacher Education in Europe (ATEE) in 1992 on the 
theme "Educational Research and Teacher Education." The founding of the European Educational Research Association in 1994, one of whose aims is "Disseminating the findings of educational research and highlighting their contribution to policy and practice" was another indication of increased interest in drawing on educational research in European teacher education. The degree of the incorporation of educational research into teacher education programmes varies a good deal between different countries (European Journal of Teacher Education, Vol.15, Nos.1, 2, 1992 and Vol.16, No.1, 1993). It is an evolving rather than a resolved issue and depends a good deal on the conception of the teacher's role which prevails.

While many traditions and methodologies of educational research contribute to the knowledge base in education, emphasis in recent decades on action research, effective schooling, curricular studies, evaluation, achievement of educational change, have been regarded by many teachers as very beneficial to their work. Obstacles which have, in the past, limited the impact of educational research on student teachers and teachers included an alleged irrelevance, problems in the mode of discourse, difficulties in dissemination, a lack of preparedness to draw upon it, as well as a lack of experience in engaging with it. In pointing the way forward to European teacher educators, Malcolm Skilbeck set out six guidelines as follows:

(i) develop in students critical-mindedness, interest in and capacity for reflective enquiry ... to see that research is no more and no less than the systematisation of this reflective, critical spirit and its translation into specific public forms of enquiry;

(ii) belp students to understand the goals, general procedures and organisation of research;

(iii) students need to be trained to practice, in a systematic way, techniques and procedures used by experienced researchers. They need to design and conduct experiments and field enquiries, to prepare questionnaires and interview and data observation schedules, to process data, to have practice in literature surveys and to be shown how to write research reports using different types of discourse; 
(iv) through the aforementioned procedures students need to acquire capacity for and interest in reading research literature;

(v) there needs to be much closer collaboration between teachers in their classrooms and university researchers;

(vi) teacher education needs to produce teacher educators and educational researchers of the next generation, particularly through research training in in-service courses (Skilbeck, 1992).

These guidelines put forward an agenda for the future with a strong professional emphasis. The fostering of critical awareness, understanding the goals of research, developing research skills through practice, fostering the ability to interpret research and engaging in cooperative endeavours with researchers, can open up new and invigorating approaches for teachers. To varying degrees, in European countries, the interface of research and teacher education is being promoted in these ways, albeit there is room for much progress (Galton, M., 1994). However, it would seem that there is a consensus regarding the importance of the research dimension. The conclusion of the ATEE Conference (1992) on this theme was that "The Conference strongly endorsed the view that educational research, both in terms of its findings and its prosecution was integral to proper teacher formation" (European Journal of Teacher Education, Vol.15, 1992).

The research emphasis is very alive in Irish teacher education. At pre-service level many students engage on action research projects and gain an orientation to educational research findings and draw on such research in completing course assignments. In certificated inservice courses teachers undergo training courses in research skills. They also engage on school-focused research assignments, while at Master's level they undertake research dissertations. At staff level in teacher education institutions scholarship and research are regarded as integral to the job profile. They engage in a wide range of research projects, including research on teacher education itself. Nowadays staff compete for externally funded research projects, frequently in association with researchers in other European countries. Since 1994 the Department of Education and Science has invited research proposals and the research committee of the Department distributes grants to projects in line with the Department's research priorities. 
This research partnership is proving to be very fruitful. The role of the Educational Studies Association of Ireland (E.S.A.I.) (founded in 1976) has been of inestimable value in promoting the cause of educational research among teacher educators and teachers, as well as fostering a co-operative collegial spirit among teacher educators throughout the country.

\section{Staffing Issues}

With the move towards university status, staff in teacher education institutions generally have to fulfil the entry requirements normally sought from other university appointees. Thus, in the great majority of cases, staff need to be university graduates of high academic achievement, usually holding post graduate masters or doctoral degrees. Those recruited for Educational Studies, per se, usually need to have a good track record in teaching and have some distinctive achievements to their credit in some feature of educational practice. Publications and involvement in educational research activities are also sought. Thus, the staff profile is now seeking academic and research achievement as well as distinguished, practical teaching experience. Most teacher education institutions employ part-time staff for particular purposes, e.g. subject pedagogy. In these instances, the emphasis is on demonstrated experience and expertise in classroom teaching, curriculum innovation or in teaching supervision. This tradition is very alive in Ireland as is also an emerging trend of seconding practicing primary teachers to serve in colleges of education.

As in other areas of higher education, staff development is an established feature for teacher educators. With the pace of change in educational studies and educational policy, it is regarded as vital that teacher educators keep themselves well abreast of their subject areas. The provision of sabbatical leave to engage in exchange or development experience is a normal pattern. Financial support and leave facilitation are also available for staff to attend conferences/seminars in their professional areas of interest. Visiting lecturers and in-house conferences provide opportunities to keep in touch with new research or developments. The normal expectation also applies of staff maintaining scholarship through reading new publications and relevant research reports. The periodic secondment 
of staff to external research projects or public service consultancy is another means of staff development. The Irish experience is very much in line with this pattern.

\section{Evaluation of Pre-service Teacher Education}

Traditionally, the education department of the state exercised close monitoring of the teacher training institutions, particularly for primary teacher education. In most European countries this has changed and the modes of quality assurance have moved into the pattern existing for university-type institutions. Greater academic freedom has become a norm. However, this also coincides with the international concern on quality assurance in higher education generally.

The United Kingdom provides a striking instance of how the state insists on retaining a very direct influence on the evaluation of teacher education courses. The government there has promoted a series of competences that determine the nature of practical assessment and it has given a greater role to school-based staff in student evaluation (Moon, 1996). The competency model is controversial, and, as yet, has not found favour in other European countries. As early as 1984 the U.K. government set up the Council for the Accreditation of Teacher Education (CATE) which was empowered, as an external monitoring agency, to exercise tight evaluation procedures on teacher education courses. This tradition bas continued and the Teacher Training Agency (TTA) succeeded CATE in 1994. It now forms part of an extensive accountability and evaluation process for higher education generally in the U.K.

The predominant pattern of evaluation in Europe relies on less direct, external processes. The main explicit measure of course quality is student assessment. In some countries the system of external examiners operates, whereby the adjudications of intemal staff are monitored by experts from other institutions. Many universities are now required to prepare annual reports which, among other things, detail research and other aspects of the performance of departments, including Education Departments. In most European countries quality assurance mechanisms for teacher education have been tightened up although it has been commented that "accountability in the southern 
(European) countries is relatively 'soft' In some countries there is no tradition of evaluation" (Montané, 1995).

In more indirect ways, school inspectorates and school employers exercise judgement on the student teacher graduates. Periodically, governments convene national reviews of teacher education programmes which allows inputs and analysis from the various stakeholders. Some countries have agencies such as Scotland's Teaching Council, and Ireland's Secondary Teachers' Registration Council, which designate certain course requirements in teacher education programmes. New legislative plans for a Teaching Council for Ireland and a Teaching Council for England aim to give the teaching profession a greater influence and recognition powers on teacher education courses (cf. Ireland, A Teaching Council, 1998).

In line with international trends in quality assurance of higher education institutions, teacher education departments form part of quality review procedures, conducted on a periodic basis. These involve whole departmental review involving internal self-appraisal followed by visits of external peer review teams. As Stern states:

The strengths of self-evaluation are considerable but are enhanced where there is management support for it from within, and technical and specialist support from outside. (Stern, OECD, 1996; p.59)

It is likely that such departmental evaluations will become more common, perhaps with an added input from other involved stakeholders.

\section{Induction}

There is a general acceptance in European countries of the value of good induction processes for the beginning teacher, but there is a lack of coherent policy on its implementation. There are very few examples of really good practice in the induction area. Interesting research and experiments have been undertaken, but there has been a failure in follow-up consolidation. Some of the most interesting induction work would seem to be in Scotland and the Netherlands. A comprehensive induction system involves much logistical planning 
and can be expensive. The tendency is, when funding is limited, to devote resources more to in-service teacher education rather than to induction. The selection, training and reward of school mentors to assist the beginning teachers present problems. Working out satisfactory partnerships between the training institutions and the schools on induction programmes has not generally been given the requisite attention. Much is demanded of school leaders in the contemporary school context and not all school leaders see a clear role for themselves in the induction process. School inspectorates in some countries have been involved in the probation of beginning teachers, but this evaluative role may cut across the guidance dimension of induction. In Ireland, the Government White Paper, Charting Our Education Future (1995) stated its support for an induction policy, but no action has taken place since, regarding implementation. Indeed, many beginning teachers face very varied, short-term and uncertain experiences as they start out in their careers, with few permanent positions immediately available. The variety of experience may have some benefits, but the general view is that these teachers' early experiences can cause serious problems which do not form a favourable foundation for a teaching career ( $S$ wan and Leydon [eds], 1996).

\section{In-service Teacher Education}

For a considerable period of time European countries have accepted the need for providing in-service education and training for teachers. This has become more strongly affirmed in the context of a lifelong learning education policy. There is a wide variety of types of inservice education and also a multiplicity of providers. In most countries these include teacher education institutions which, in the past, were largely focused on pre-service teacher education. The duration of courses varies from long duration courses leading to certification to short-term, sandwich and summer courses. In most countries participation in in-service teacher education (INSET) is on a voluntary basis, but in a few countries it is part of contractual obligations. Most countries operate in-service provision partly on school time and partly on personal time. In some countries, as, for instance, Great Britain, some non-teaching contract time is devoted to collegial planning and in-service activities. Promotion prospects also tend to be affected by evidence of participation in INSET. 
Space does not allow for an extended treatment of trends in INSET. However, best practice tends to incorporate features such as those identified in the OECD report, Staying Ahead: In-service Training and Teacher Professional Development (1998, pp.53-59). Thus, it is regarded as desirable that INSET should incorporate both on and off-site school dimensions. Teachers ought to bave a role in setting the agenda. The active engagement of teachers in the process and the use of experiential techniques are favoured. In many countries, through training of trainers' courses teachers have been assisted to work with their peers as facilitators and team leaders. This gives rise to a sense of empowerment and confidence building which cultivates an esprit de corps. Collaborative, interactional techniques are very much in favour, rather than lectures to large groups.

Another key trend is the promotion of inter school networks or clusters, wherein staff from a number of schools work together on new curricula or methodologies. Instead of a "top-down" or a "bottom-up" approach, the OECD report terms this trend as "bottom across." The OECD report also notes the crucial role of external assistance for the process and the importance of support from agencies such as higher education institutes, education centres, regional or specialist support teams. It is also recognised internationally that teacher development is often best promoted within the context of school development, and more and more schools are being encouraged to engage in collaborative development planning. While the education system's needs are prominent, this is not to the exclusion of the personal and individual needs of the teacher. The teacher's needs are also linked to INSET for career diversification and more specialism within a greatly or changing school system.

While INSET has developed greatly in recent years and has become enriched and varied, there is scope for improvement. In this context, the OECD international study commented:

Improved planning, more involvement of teachers, better evaluation and dissemination will all strengthen the concept of professional development which must be seen to begin with pre-service and continue through a teacher's. career. Professional development is not simply an "addon" or a "quick fix" to be applied when a particular problem arises (p.58). 
Ireland has broadly followed the general European pattern of INSET through the nineties. The Department of Education and Science established the In-Career Development Unit (I.C.D.U.) to help co-ordinate and finance a good deal of the INSET. The outgoing National Development Plan allocated $£ 40$ million for INSET and the

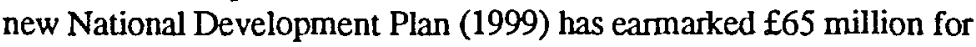
this purpose over the duration of the Plan. These figures do not cover the full costs of INSET but they indicate a progressive view which regards such expenditure as an investment in the human resources of the system. Rigorous co-ordination is perhaps less of a concern than it was some years ago. Some very interesting and worthwhile initiatives have been undertaken by a wide variety of agencies, and a case can be made to let "all the flowers bloom," once evaluation shows them to be worthwhile. A new teacher culture is being shaped and the Irish experience of INSET over recent years seems to be in line with good international practice.

\section{The Teaching Career}

A great deal could be written about the developments and changes within the career of teaching in Ireland which have been taking place. However, as a conclusion, I would wish to refer to just two issues. One is the relationship which has prevailed between government policy and the teachers and teacher education. Both the Green Paper (1992) and the White Paper (1995) paid generous tribute to the teaching profession and expressed government intent to protect and promote the best interests of the profession. Repeatedly, Irish government ministers have displayed a warmth of view and regard for teachers. In a period of great change, this understanding and good relationship is of considerable importance and has by no means been the experience in all other Western European countries.

The second important issue to which I would draw attention is the government's intention, in line with the views of many educators and representatives of the public, to establish a self-governing Teaching Council. A Bill has been prepared on the basis of a report from a technical working group and a representative steering committee, the Report On The Establishment Of A Teaching Council (1998). The Bill has not been published to date, but if it follows the lines of the Report, Ireland will have the most comprehensive and broad-ranging Teaching 
Council, not just in Europe, but in the world. The establishment of the Teaching Council in the first year of the new century would be a powerful symbolic testimony to public regard for the teaching profession. Such a Council if it adopted a proactive, synergistic approach to its brief, could indeed, set a headline for the rest of Europe. 


\section{REFERENCES}

Aldrich, R. and Crook, D. (1998)

"Education as a University Subject in England: An Historical Interpretation" in Paedagogica Historica, Supplementary Series III, pp.121-138.

Beemaert, Y. (1995)

"General Report on Winter University on European Teacher Education" in Michaelsson, P.E. (ed.) Winter University Proceedings, ATEE, Dalarna University 1995, pp.172-189.

Bone, T.R. and McCall, J. (1990)

Teacher Education in Europe: The Challenges Ahead, Glasgow, 1990.

Buckberger, F. (1994)

"Teacher Education in Europe - Diversity versus Uniformity" in Galton, M. and Moon, B. (eds) Handbook of Teacher Training in Europe: Issues and Trends, London: Fulton, 1994, pp.14-52.

Buckberger, F. (ed.) (1992)

Guide to Institutions of Teacher Education in Europe, Brussels: ATEE.

Burke, A. and Coolahan, J. (1995)

"Teacher Education and the Teaching Profession in Ireland in an Era of Educational Change" in Michaelsson, P.E. (ed.) op.cit., pp.65-88.

Coolahan, J. (1991)

"Teacher Education in the Nineties: Towards A New Coherence" in Coolahan, J. (ed.) Teacher Education in the Nineties, Limerick: ATEE, 1991.

Coolahan, J. (1991a)

"Teacher Education and the Universities: Ireland", European Journal of Teacher Education, Vol.14, No.3, pp.287-296.

Coolahan, J. (1995)

"Teacher Education and the Teaching Profession in the West European Region" in Michaelsson, P.E. (ed.) op.cit., pp.44-52.

Collins, U.M. and McNiff, J. (1999)

"Contextualising the Work" in Collins and McNiff (eds.) Rethinking Pastoral Care, London and New York: Routledge, pp.7-14. 
Drudy, S. and Uí Chathán, M. (1999)

Gender Equality in Classroom Interaction, Maynooth, National University of Ireland.

Edwards, A. (1998)

"Mentoring Student Teachers in Primary Schools", European Journal of Teacher Education, Vol.21, No.1, pp.47-62.

Elle, B. (1995)

"Education of Primary and Lower Secondary Teachers in Denmark" in Michaelsson, P.E., op.cit., pp.14-32.

Elliot, J. (1993)

Reconstructing Teacher Education, London: Falmer, 1993.

European Commission (1995)

Teaching and Learning: Towards the Learning Society, Brussels.

European Commission Study Group on Education and Training (1997)

Accomplishing Europe Through Education and Training, Brussels.

European Journal of Teacher Education, Vol.15, Nos.2,3, 1992 and Vol.16, No.1, 1993, Special Editions on "Educational Research and Teacher Education in Europe".

Galton, M. and Moon, B. (eds) (1994)

Handbook of Teacher Education in Europe, London: Fulton.

Galton, M. (1994)

"Teacher Training in Europe: A Research Agenda" in Galton and Moon, op.cit., pp.181-215.

Hudson, A. and Lambert, D. (eds) (1997)

Exploring Futures in Initial Teacher Education, London Institute of Education.

Ireland, (1998)

Report on the Establishment of a Teaching Council, Dublin: Stationery Office.

Judge, H. (1991)

"Teacher Education and the Universities" in special edition of The European Journal of Education, Vol.14, No.3, pp.257-262.

Koster, B., Korthagen, F.A.J. and Wubbels, T. (1998)

"Is There Anything Left for Us? Functions of Co-operating Teachers and Teacher Educators", European Journal of Teacher Education, Vol.21, No.1, pp.75-90. 
Michaelsson, P.E. (1995)

Proceedings of the Winter University on Teacher Education in Europe, Dalarna University, ATEE, 1995.

Montané, M. (1995)

"The Need for a Common Education Policy in Southern Europe", in Michaelsson, op.cit., pp.147-150.

Montané, M. and Bordas, I. (1992)

"Teacher Education in Spain" in Buckberger (ed.) op.cit., pp.179-306.

Moon, B. (1996)

"Practical Experience in Teacher Education : Charting A European Agenda", European Journal of Teacher Education, Vol.19, No.3, pp.217-248.

Neave, G. (1987)

Change and Challenge: The Mobilisation of Europe's Teachers, Council of Europe, Netherlands: Noordwijkerhout.

OECD (1998)

Keeping Ahead: In-service Training and Teacher Professional Development, Paris.

Sander, T. (ed.) (1994)

Current Changes and Challenges in European Teacher Education, Brussels: ATEE.

Schon, D.A. (1987)

Educating The Reflective Practitioner, London: Jossey-Bass.

Skilbeck, M. (1992)

"The Role of Research in Teacher Education", European Journal of Teacher Education, Vol.15, Nos.2, 3.

Stern, E. (1996)

"Developmental Approaches to Programme Evaluation" in OECD, Evaluating and Reforming Education Systems, pp.4760.

Swan, D. and Leydon, M. (eds) (1996)

Teacher Induction, Dublin.

Todeschini, M. (1992)

"Teacher Education in Italy" in Buckberger, F. (ed.) Guide to Institutions of Teacher Education in Europe, Brussels: ATEE, pp.187-193. 
Townsend, J. (1994)

"Developments in School-Based Initial Teacher Training", European Journal of Teacher Education, Vol.17, Nos.1-2, pp.49-53.

Vonk, J.H.C. (1991)

"Some Trends in the Professional Preparation of Teachers in Europe" in Coolahan, J. (ed.) Teacher Education in the Nineties: Towards A New Coherence, ATEE, Limerick, 1991.

Zabalza Beraza, M.A. (1996)

"Practical Experience in Teacher Education : Its Meaning, Value and Contributions", European Journal of Teacher Education, Vol.19, No.3, pp.269-271.

Zanting, A., Verloop, N., Vermunt, J. and Van Dricl, J.H. (1998) "Explicating Practical Knowledge : An Extension of Mentor Teachers' Roles", European Journal of Teacher Education, Vol.21, No.1, pp.11-28. 